\title{
УДК 614.252.2:615.1 \\ НООСФЕРНО-ЕКОЛОГІЧНИЙ ІМПЕРАТИВ ЯК ОСНОВА СУЧАСНОГО СВІТОГЛЯДУ ЛІКАРЯ ПРОФІЛАКТИЧНОЇ МЕДИЦИНИ
}

\author{
О. А. Шевченко, Н. І. Рублевська, Ю. С. Крамарьова
}

ДЗ “Дніпропетровськамедична академія МОЗ України”

\section{NOOSPHERIC-ECOLOGICAL LEVEL OF DEVELOPMENT AS A BASIS OF MODERN CONCEPTION OF THE WORLD FOR DOCTORS OF PREVENTIVE MEDICINE}

\author{
O.A. Shevchenko, N. I. Rublevska, Yu. S. Kramarova \\ SI "Dnipropetrovsk Medical Academy of MPH of Ukraine"
}

\begin{abstract}
3 метою забезпечення подальшого існування людства на сучасному етапі розвитку імперативної бази соціуму назрілою необхідністю є перехід до ноосферо-екологічного імперативу. Особливо важливим с доповнення традиційних засад підготовки лікарів профілактичної ланки з урахуванням основ нового наукового напрямку - екології людини.

On the purpose of future human being in the modern condition of social development it's necessary to put into noosphericecological level of development. Therefore it's important to improve traditional system of education of specialists in the branch of medical-prophylactic medicine with it scientific part - ecology of the man.
\end{abstract}

Вступ. Сто років тому великий гуманіст Махатма Ганді казав: "У природи завжди вистачить ресурсів, щоб забезпечити людські потреби, але їх ніколи не стане, щоб задовольнити людську ненажерливість”. Наприкінці XX сторіччя остаточно стало зрозумілим, що протиріччя між зростаючими матеріальними потребами людства і відносно обмеженими можливостями біосфери ставлять під загрозу подальше існування антропосфери. Всесвітня конференція ООН з навколишнього середовища та розвитку у Ріо-де-Жанейро у 1992 році виробила концепцію переходу сучасного суспільства до так званого “сталого розвитку”, тобто до нової цивілізаційної епохи на підгрунті радикальної зміни цілей та цінностей сучасного суспільства, орієнтації на гальмування подальшого зростання матеріальних запитів людини. На зміну суто споживацькому по відношенню до навколишнього природного середовища світогляду приходить розуміння, що тільки співрозвиток, співтворчість, або коеволюція з біосферою дозволить людству піднятись до розуміння універсальних законів, що правлять світом [1].

Вперше концепція коеволюції, як шлях до гармонізації взаємовідносин соціуму та біосфери, була висловлена у 1968 році академіком Миколою Тимофєєвим-Ресовським. Головна ії ідея полягає в тому, що змінюючи біосферу відповідно до своїх потреб, людство повинно також змінюватись з урахуванням об' єктивних вимог природи. Глибинні зміни світогляду людини у планетарному масштабі потребують не тільки часу, якого у людства залишилось обмаль, а й головне - докорінного перегляду системи імперативів, тобто універсальних обов'язкових до виконання правил існування. В цьому сенсі сьогодні ноосферо-екологічний імператив можна вважати найсуттєвішим для людства втіленням категоричного (морального) імперативу I. Канта - “вчиняй так, щоби максима твоєї волі могла мати в той же час силу принципу загального законодавства" [2]. Вважається, що причини сучасної глобальної екологічної кризи слід шукати у сфері людської духовності, яка трансформувалась від ідей сліпого поклоніння природі до необмеженої експлуатації іï ресурсів. Саме орієнтація на споживання та постійне покращення матеріального добробуту спонукають людину на збільшення техногенної діяльності, що призводить до поглиблення екологічної кризи і наближає ноосферо-екологічний імператив до категоричного і єдино можливого для подолання перманентної загрози знищення життя на планеті.

Отже, подальше існування соціоприродної цілісності може відбуватись тільки на основі ноосферо-еколо-

() О. А. Шевченко, Н. І. Рублевська, Ю. С. Крамарьова 
гічного імперативу, який буде керувати суспільством, що вступило на шлях коеволюційного, єдино можливого для його виживання, розвитку.

Основна частина. Практичне втілення ноосферно-екологічного імперативу може відбуватись за умови нерозривного зв' язку наукових досліджень, громадської діяльності, та головне - виховання і освіти майбутніх найбільш активних членів суспільства. В цьому сенсі вкрай важливим ми вважаємо розробку та втілення нових підходів до формування ноосферно-екологічного мислення майбутніх лікарів-профілактиків - студентів медико-профілактичних відділень та лікарів-інтернів. Зазначимо, що завданням науки гігієни та санітарії, як їі реалізації у практичній діяльності, є вивчення впливу факторів довкілля, умов життя і праці на організм людини та профілактика хвороб для збереження здоров'я і подовження життя. За Е. Спарксом, головна мета гігієни - “... зробити розвиток людського організму найбілыш довершеним, життя - найбільш сильним, згасання - більш уповільненим, а смерть - найбільш віддаленою”. У зв'язку з цим традиційно при підготовці лікарягігієніста у медичних ВНЗ головним завданням для формування його професійного світогляду є прищеплення так званого “гігієнічного мислення”, яке поряд 3 “клінічним мисленням” студентів лікувальних фахів становить наріжний камінь подальшої успішної лікарської діяльності та мотиваційну основу прийняття самостійних професійних рішень [3]. Не торкаючись історичних аспектів еволюції цих категорій, зазначимо тільки, що вони великою мірою можуть бути інтерпольовані на сутність ноосферо-екологічного імперативу, який повинен забезпечити перехід людства від принципу “реагування та виправлення” до принципу “активної профілактики”. Дослідження етіологічної еволюції хвороб людства у ХХ сторіччі переконливо доводять, що все більший їх відсоток припадає на так звані екологічно обумовлені захворювання, спричинені техногенно зміненими об' єктами довкілля, які зазнали впливу хімічних, фізичних, біологічних факторів у процесі людської діяльності.

Вважається, що в екологічно напружених регіонах, до яких в Україні, зокрема, відносяться індустріальне Придніпров'я та Донбас, питома вага екологічних чинників у формуванні рівня здоров'я мешканців, особливо дітей, може сягати 35-40 \%. Необхідність задовольнити зростаючі потреби людства у харчових продуктах у зв'язку із невпинним збільшенням його чисельності, змусило вчених відкрити ще одну “скриньку Пандори” - втрутитись у генетичний код живих істот для отримання рослин з небаченими дотепер “корисними” властивостями. Передбачити віддалені наслідки такої діяльності, а отже своєчасно і ефективно запобігти їм практично неможливо. Таким чином, слід визнати, що ефективна практична реалізація головного суспільного призначення лікарів-гігієністів - профілактики порушень здоров'я окремої людини та груп населення під впливом факторів оточуючого середовища в сучасних умовах і у майбутньому неможлива без розвитку концепції “гігієнічного мислення" в напрямку осмислення та прийняття ноосферо-екологічного імперативу. За цим стоїть велика праця, яка має переорієнтувати наше світосприйняття з антропоцентризму на біоцентризм. Робота в цьому напрямку повинна починатись саме з перебудови системи виховання та професійної освіти, в першу чергу фахівців-екологів, медиків, управлінців органів самоврядування. Зазначимо, що ідея біоцентризму в даному випадку не суперечить принципу гуманізму та не заперечує найвищої цінності людини, оскільки будь-яка система цінностей, побудована людиною, несе на собі ії відбиток і тому буде значною мірою антропоцентричною.

Отже, на сучасному етапі сформульована головна умова коеволюційного розвитку - прищеплення суспільству ідеї ноосферо-екологічного імперативу, який гармонізує соціоприродну цілісність людства та отримує практичне втілення у ноосферній освіті, зокрема у новому науковому напрямку - екології людини [4].

Висновок. Беручи до уваги назрілу необхідність осмислення та практичного втілення у суспільстві ноосферо-екологічного імперативу, можна стверджувати, що сучасна система підготовки лікаря-гігієніста на переддипломному та післядипломному етапах повинна стати більш екологічно орієнтованою та здійснюватись у руслі наближення до нового наукового напрямку сучасності - екології людини. Це вимагає подальшого розвитку і переосмислення традиційної ідеології профілактичної медицини з переважно антропоцентричною системою цінностей та формування на іiі базі сучасних навчальних програм для освіти і виховання майбутнього лікаря-гігієніста. 


\section{ВДОСКОНАЛЕННЯ ВИЩОЇ МЕДИЧНОЇ ОСВІТИ}

\section{Лiтература}

1. Некрасов С. И. Современные проблемы коэволюции / С. П. Некрасов, Н. А. Некрасова, С. А. Кутоманов. - Изд-во “Академия естествознания”, 2010.-350 с.

2. Кант И. Сочинения : в 6 т. / И. Кант. - М. : Мысль, 1963. $-\mathrm{T} .1 .-543 \mathrm{c}$.

3. Гигиена с основами экологии человека : учебник /
В. И. Архангельский и др. ; под ред. П. И. Мельниченко. М. : ГЭОТАР-Медиа, 2010.-752 с.

4. Маслова Н. В. Ноосферное образование : концепция, методология, технология /Н. В. Маслова.-М. : РАЕН, 1999. $-338 \mathrm{c}$. 